\title{
Liberation Theologies, Periphery Existence, and Global Challenges: Towards a Transcultural Ideology of Liberation
}

\begin{abstract}
By Bettina Koch ${ }^{*}$
In Islamic Liberation Theology: Resisting the Empire (2008), Hamid Dabashi claims that Islamic ideology of the last 200 years as well as Latin American liberation theology does not offer any adequate responses for challenging empire under twenty-first century conditions. This paper is appreciative of Dabashi's general project and explicitly agrees with him that replacing the oppression of old colonial or new colonial powers, whether they are nations or manifestations of global capital, by the oppression of a (totalitarian) religious ideology does not solve any problems, but creates just new ones. Contrary to Dabashi, the paper argues that both, Islamic ideology as it has been developed in response to European colonialism as well as Latin American liberation theology and liberation philosophy has ideas to offer that allow for a new ideology that fulfills the most significant aspects of Dabashi's demands: being liberating and being part of a global conversation. For this purpose, this paper draws chiefly on José Comblin Enrique Dussel, Ignacio Ellacuria, and 'Ali Shari'ati (and al-Afghani). In addition, the paper discusses the challenges of any ideology of liberation, particularly in the context of the "global war on terror." In this sense, the essay is also a contribution to the ongoing debate on national security.
\end{abstract}

\section{Introduction}

In Islamic Liberation Theology: Resisting the Empire, Hamid Dabashi claims that neither Islamic ideology of the last 200 years nor Latin American liberation theology offer any adequate responses to challeng empire under twenty-first century conditions. Dabashi asks for a "radical rethinking of the very notion of ideology - whether in its secular or theological variations" (Dabashi 2008: 14). Primarily, he opposes totalitarian religious ideologies that worsen the conditions of oppression instead of improving the people's conditions because, according to Dabashi, the "worst aspect of Islamic ideology was its persistent reliance on Islamic Law (Shari'ah), the consequences of which for a free and democratic society is simply catastrophic, for it mutates the free and autonomous citizen of a potential republic into the legal subjects of a medieval jurisdiction" (Dabashi 2008: 263).

*Associate Professor, Virginia Polytechnic Institute and State University, USA. 
Dabashi, however, neither clarifies what exactly he means by "empire," nor does he illuminate what and by whom it has to or should be challenged. While his arguments against radical Islam and other religious extremism are worth considering, this essay aims at contesting Hamid Dabashi's thesis that neither Islamic thought nor Latin American liberation theology has anything to offer in order to challenge what he phrases as "empire." For this purpose, the essay first clarifies what could be meant by empire that, according to Dabashi, has to be challenged. Second, it discusses the problem of exclusion and oppression and the suggested solutions as explored by al-Afghani, "Ali Shari'ati, Ignacio Ellacuría and José Comblin. Third, it examines the challenges of preventing religious and social movements from turning violent and extremist. The last section builds on the author's previous research that suggests that the cause of most "religious" conflicts is not religion or religious interpretation, but is the outcome of unsolved and intensified socioeconomic and political problems, usually involving severe versions of injustice and exclusion (Koch forthcoming). This perspective is also supported by Hans G. Kippenberg (2011: 200), who suggests that even if a conflict is not caused by religion, it does not mean that religious interpretations of a conflict are avoided. Yet, a religious interpretation alters a conflict's nature, which means that through religious interpretation a socio-economic or political conflict can be perceived as and eventually transformed into a religious conflict, while the socio-economic or political origin of a conflict gets forgotten, even though the original causes of conflict remain.

Because the essay aims at a common ground among Muslim and Christian thinkers, it brings the aforementioned thinker into cross-cultural dialogue. The dialogical approach fits into the paper's larger theoretical framework as a contribution to Comparative Political Theory. Cross- and transcultural dialogue has been particularly promoted by Fred Dallmayr (Dallmayr 2008). While (and for good reason) one can be skeptical about the dialogical approach (Bashir 2013), the paper's topic aims at a dialogical perspective of peripheral Latin American and Middle Eastern thinking. To increase the intersection between the two cultures involved, the paper treats problems phrased in religious language as moral or ethical problems. Yet, the essay's scope goes far beyond a pure dialogue, but challenges the mainstream narrative of religious violence and religiously motivated terrorism that poses a threat to national security in the so-called West, particularly to the United States (Ahmed 2013).

\section{Empire: Center versus Periphery}

The concept of "empire" is usually associated with the notion of hegemony and economic and political power, occasionally referring to the former or current super power(s) (the US and the Soviet Union/Russia), former colonial powers such as Great Britain, France, or Italy, or the West, used synonymously for the industrial or first world. While analyzing a particular case and emphasizing the particular challenges of, say, British rule in India, has 
its merits, such an approach undercuts any insights that allow for the identification of structural similarities between different hegemonic experiences. To put it with Akbar Ahmed, "[t]o many in the independent nations, the arrogant, aloof, and culturally alienated white sahib of the colonial administration was replaced by an equally arrogant, aloof, and culturally alienated black sahib of the new administration. Many in the rural and tribal areas were discovering that little had changed in spite of the promises of the founding fathers, who themselves were now the object of the people's wrath" (2013: 177).

Moreover, whereas José Comblin (1979) critically analyzes the "national security state" of the Latin American military juntas that were part of a larger trans-regional anti-communist geopolitical strategy, Charles Tripp emphasizes that the strategic preference for the national security system is or was not limited to Latin America, but remains significant in the Middle Eastern regions (2013: 51-60), even though the master narrative of the Cold War that emphasized a communist threat has been replaced by a new master narrative of an international threat of terrorism that is rooted in Islamic radicalism. By contrast, one of the counter-narratives identifies the origin in non-state violence in "the relationship between center and periphery" (Ahmed 2013: 331). Ahmed's underlying concepts of periphery and center corresponds with Enrique Dussel's. Dussel explicitly includes "the marginalized homeless, impoverished people in countries of the 'center' [but also] ecologists, feminists, and excluded races" in his understanding of the periphery (Dussel 2013: 355). His and Ahmed's perspective allows and asks for the inclusion of local or regional elites into the center, while the excluded remain part of the periphery, independently of their geographical location and cultural belonging. In this sense, the center means access to power, resources, and political, economic, and social participation, whereas the periphery is associated with exclusion from power, resources, and political, economic, and social participations. The fundamental nature of this distinction does not change, independently whether it is phrased in religious, Marxist, or any other language, although the particular languages used may favor the justification for exclusion based on religious creed, ethnical origins, class, and so on. In this sense, the socioeconomic and political elites of the "center" in Bucharest, Tripoli, Bogota, or London have far more in common with each other than with their local periphery, or, to adopt Camilo Torres's language, the subcultures of the center and the periphery are more divided than the center-culture globally (Torres 1971a). Increasingly, one can observe a new and orchestrated rhetoric used by the centers:

"Painting their peripheries as associated with al Qaeda, many countries have sought to join the terror network because of the extensive benefits that it brings. They use the rhetoric of the war on terror to both justify their oppressive policies and to integrate 
themselves with the United States and the international system" (Ahmed 2013: 289).

As indicated above, this "new global paradigm" follows a similar logic as the previous anti-communist paradigm of the Cold War era. The periphery's critique is often voiced in religious language, often referring to the dichotomy of true and false religion; the latter is frequently framed and phrased as a religion that supports a status quo that is perceived as unjust. The frequent and returning issues are injustice and exclusion. Thus, the religious language is used as a religious ethics that addresses problems that are not religious, but contradict a particular religious ethics or religious values (Osborn 1983: 81-2). Frequently, authors borrow from other "ideologies" that support a particular (religious) ethics. For instance, the liberation theologian Juan Luis Segundo's responded to Cardinal Ratzinger's critique of liberation theologians' attempts to integrate some Marxist ideas into liberation theology by emphasizing that frequently "writers from one school of thought borrow and incorporate an element from another school with no apparent harm done" (cited in Pottenger 1989: 81).

\section{Two Religions}

In the Islamic and Christian religious traditions one encounters the merging of "traditional, religious values with a commitment to social activism on behalf of the "poor and oppressed"' (Pottenger 1989: 1). Whether such a response is generated under conditions of colonialism, authoritarianism, neocolonial underdevelopment, economic crisis, a real or imagined terrorist threat, or a mixture of different factors, is only of secondary interest. The status quo is perceived as unsustainable; change and actions that can stimulate change are considered mandatory. What is at the heart of the thinking that unites the Muslim and the Christian thinkers is their conception of two religions, two Islams and two Christianities, a true version and a false version. In both religious-cultural contexts, the false version of Islam or respectively Christianity is associated with the status quo, with hegemony and oppression. In other word, whereas religion is part of the problem, they also claim that religion, properly understood, can be also part of the solution. Here, religion is primarily a tool to promote morality and ethics in order to criticize and to undermine the legitimacy of the status quo.

One of the clearest expressions of this distinction between the two religion we owe to 'Ali Shari'ati who sees a similar division of two religions not only in Islam, but also in Christianity and Zoroastrianism. Corresponding to Dabashi's critique of the totalitarian nature of religious law, particular if it is the foundation of the state, Shari'ati never mentions the needs for an Islamic state or the necessity to introduce coercive Islamic laws (Chatterjee 2011: 94). Yet, for Shari'ati, there are "two kinds of religions - one of which has always been against the other. [...] We have an Islam that commits crime, creates 
reactionaries, concocts opiates, murders freedom, and protects the status quo." This Islam he contrasts with another Islam, "the true one that has always fought with its criminal counterpart and in the process it has been victimized" (Shari'ati 1981: 86).

He assumes two hostile poles, each armed with religion, that have always existed and continue to fight one another. One pole represents "corruption, crime, exploitation, ignorance, slavery, racism, imaginary virtues, and impediments to human progress." The other pole stands for and stands up for "justice, human consciousness, growth, and [the] struggle to unite humanity." Shari'ati describes the conflict between these two poles as a war between religion. I use the singular by purpose. By this war he does not mean a war between different creeds, but between contrary interpretations within one religious tradition (Shari'ati 1981, 17). In other words, Shari'ati draws on the difference between "true religion" and the religion of "ignorance, poverty, and absolute submission" (Shari'ati 1986: 48).

In order to change the existing situation, Shari'ati is calling for an "enlightened" person who is grounded in the culture; this enlightened person understands the "inner pains of his society" and does not try to bring change through un-reflected imports from other cultures, particularly the Western cultures (Shari'ati 1986: 8). Despite his admiration for Camus, Sartre, or Brecht, he concludes that they do not speak to any of the problems he regards as specific to his own culture, particularly to prerevolutionary Iran. As Shari'ati puts it, "Brecht's prescription is not good for my pain; he has a neurological problem, but I have a stomach ache" (Shari'ati 1981: 34). Imitating, for instance, Sartre in India would be similarly useless (Shari'ati 1986: 9). Shari'ati's enlightened figure has to be aware of the "deviant and reactionary elements" that abuse religion as a weapon; this weapon is used to distract the people/the masses from the material problems at hand by keeping them occupied with concerns about their afterlife (Shari'ati 1986: 20).

According to Shari'ati, the imperialists and colonialists sought the elimination of religion; when religion is eliminated "the bomb of submission can be dropped in the heart of the Muslim society." Secularized elites have replaced their religion with the "religion of the market place" and a "new slavery" (Shari'ati 1986: 33-4). This implicit critique of neoliberalism is phrased in religious terms because it is understood by the common people and because of the lack of alternative sources for an ethics of liberation, for an ethics that allows for a transformation of the status quo. Yet, for Shari'ati, the real and most dangerous enemy is not the foreign imperialist. The enemy comes from within. To cite 'Ali Shari'ati in length, "[t]he most dangerous enemy is the oppressor who is clad in the attire of Islamic justice, an idol worshiper, human worshiper. [...] an individual who is the guardian of ignorance and narcotizing, the propagator of superstition, lies, and illusion, the agent of social stagnation, and baseness, one who deceives people and, in the na"me of Islam, asks people to forget their destiny, poverty, and wretchedness, and to ignore the danger of their enemies' conspiracy, one who, in order to 
please the destinies of the earth, in the phony attire of piety for the pleasure of Allah persuades people to accept the status quo" (Shari'ati 1986: 36).

Shari 'ati accuses the so-called "guardians" of the religion of having turned religion into dead rituals and rites, which has destroyed the religion and "made it lifeless, directionless and motionless" (Shari'ati 1986: 38).

'Ali Shari'ati's analysis corresponds to al-Afghani's, who associates the reasons for Islam's decline in fanaticism, meaning the "misuse and misinterpretation of religion with the intention of legitimizing the existing religious and social order," and tyranny (Jansen 1997: 27). Al-Afghani attacks the traditional establishment that opposes science and knowledge and therefore progress and development. They honor Aristotle as if he would be a pillar of Islam but consider Galileo, Newton, and Kepler infidels. Al-Afghani emphasizes that "the father and mother of science is proof, and proof is neither Aristotle nor Galileo. The truth is where there is proof, and those who forbid science and knowledge in the belief that they are safeguarding the Islamic religion are really the enemies of that religion" (al-Afghani 1983a: 107).

In this sense, he regards traditional religion or the religion of the status quo as a hindrance to development and progress. Moreover, by using both religious and profane language, he condemns injustice, tyranny and oppression, and the hostility towards scientific and philosophical truth. Ideally, he demands a republican government, founded on the principle of justice (al-Afghani 1966: 21). Although al-Afghani is less explicit about the two concepts of religion that are essential in Shari'ati's thinking, al-Afghani attacks the traditional religious establishment for the very reasons Shari'ati does some decades later.

Shari'ati's analysis, however, corresponds excellently to Latin American liberation theology. For José Comblin, one of the "major architects" of the Medellín Conference (French 2007: 421), the key theological concern rests in the difference between "right" and "wrong" theologies. Whether a theology qualifies as right or wrong depends on its situated-ness. He notes, "in any human situation, in any debate, there is a right statement and wrong statement, a right attitude and a wrong attitude" (Comblin 1979: 12, 14). Similarly, he distinguishes between a "true theology" and an "established theology." To him, false theology exists if it understands itself as a complete system of "truth" the believers are expected to listen to and to obey. It is a "theology of silence" that is an "expression of power" and an "ideology of privileges." He equals the false or established theology with the orthodoxy of the institutionalized Church; it conflicts with the "true theology" that "does not want to ignore the problems of the world at a given time. [...] Rather, it wants to restore in the world the hope of the poor so that their voice can be heard." For Comblin, a theology that is not situated in history, in time, is empty and meaningless (Comblin 1979: 16, 19, 22). This distinction also relates to the two churches: the Church that represents the institutional Church's upper hierarchy that helps and always helped legitimizing power of kings and emperors, and the church of 
the lower echelon that follows a democratic and spiritualistic tradition and is bound to the principles of social justice and charity (Comblin 1979: 43). ${ }^{1}$

This understanding of a theology in the hic et nunc is paradigmatic for liberation theology and finds one of his earliest and clearest expressions in Gustavo Gutiérrez exploration of liberation theology as political. For Gutiérrez, liberation theology is "political theology" in the sense that it deals "with the classic question of the relation between faith and human existence, between faith and social reality, between faith and political action" (Gutiérrez 1988: 29). Similarly, both al-Afghani and Shari'ati are frequently associated with the invention of political Islam. In Gutiérrez's reading, the concept of political theology relates the current struggle for liberation that requires social revolution to change the existing order and involves "counterviolence [that opposes] the violence which the existing order produces" back to the historicity of Jesus' mission. Being in the world and responding to the existing injustice has a political dimension (Gutiérrez 1988: 130, 135).

By stressing the political character of Jesus, Ignacio Ellacuría puts an even stronger emphasis on the historicity of religion and its interpretation (theology), which he reads as a sometimes more, sometimes less effective liberation movement (Ellacuría 1976: 67). For Ellacuría, from a theological viewpoint, there is only one historical process: "It is one of liberation from injustice leading towards liberty in love." Liberation means struggle against injustice (Ellacuría 1976: 109-10). But how, he asks, "can a Church which contributed so much towards the injustice and oppression of the world claim liberation and the struggle for injustice as signs of its credibility?" In response, he distinguishes between a Church that has been faithful to her mission and a Church that has betrayed her mission (Ellacuría 1976: 113). A Church that is not true to her mission, explicitly or implicitly, supports the status quo and, particularly in the Latin American context Ellacuría was referring to, structural violence caused by political, social, economic, and religious power (Ellacuría 1976: 166).

What 'Ali Shari'ati has phrased as true and false religion reappears in Ignacio Ellacuría in reference to two types of violence, "the first is the root kid of violence [...]. It is presented as injustice, and it is immersed in the mystery of inequity. [The second] is presented as resistance to the situations which in themselves are violent because they violate human dignity and oppress man's liberty" (Ellacuría 1976: 170). The first type of violence Ellacuría pairs with injustice. Primarily, he sees three versions of abusive power that are "unjust and violent:

1) legislation that tries to perpetuate an unjust situation in the political and socio-economic order;

2) political torture in all its forms;

${ }^{1}$ Gismondi (1986: 20) implies that Comblin overdraws the distinction between the two churches, particularly in historic perspective. 
3) falsehood propagated deliberately to misguide the consciences and conscious awareness of the people. This would be covert, legalized violence, but it remains the worst violence of all. It is unjust violence, or, the violence of injustice (Ellacuría 1976: 198).

The first and the second unjust violence correspond to institutionalized social injustice Ellacuría regards as the "highest magnification of violence." From a Christian perspective, he calls it "a very grave" sin because it is "the result of real human sin and of sinful attitudes: the desire to dominate, contempt of human beings, envy and overweening pride, egotism and everything else that directly opposes charity" (Ellacuría 1976: 199).

While the institutionalized Church supports the status quo and a "sinful structure," true Christians are "summoned to work against injustice and for development, for the establishment of a new world order where oppression and unjust inequity will be forever blotted out." By contrast, those who defend the existing order, the status quo of injustice and oppression, lack Christian authenticity (Ellacuría 1976: 172, 208). Ellacuría as a Jesuit priest reemphasizes the problem of oppressive structures in the language of redemption. "Violence must be redeemed." Redeeming violence is "redemption of sin," which may require the use of violence itself, but only violence of the second type he does not consider as violence in the strict sense.

\section{Periphery Ethics?}

If one scans through the previous quotations describing true and false religion in both religious traditions, false religion is associated with crime, creates reactionaries, murders freedom, corruption, exploitation, ignorance, slavery, racism, poverty, hinders human progress, social stagnation, tyranny, injustice, (structural) violence, illegitimate socio-economic and political order, torture, exclusion whereas true religion stands for (social) justice, human consciousness, growth, united humanity, progress, development, democracy, true spirituality, charity, freedom, unity. If one excludes terms with a particular religious connotation, the religious thinkers aim at (social) justice, growth, development, unity, progress, democracy, and freedom. In other words, they aim at overcoming the marginalization of the periphery with all its consequences.

Although 'Ali Shari'ati, al-Afghani, José Comblin, and Ignacio Ellacuría phrase their critique of the status quo in religious terms and although they are explicitly attacking a religious establishment that defends the status quo and has become an oppressive power itself again in religious language, the structural analysis is in both contexts, at least if one abstracts from some particulars, similar. Indeed, their analysis, although it originates in the context of British colonialism (al-Afghani) or the Cold War (Ellacuría, Comblin, Shari'ati), describe disadvantages of the periphery that still exist, whether it concerns the Kurdish minority in Turkey, tribal groups in Pakistan, 
Afghanistan, or Mali, or the Uyghurs in China (Ahmed 2013: 274-299). As the authors that have been discussed, these groups oppose the socio-economic, political, and social injustice they experience; they oppose hegemonic domination and oppression. Although injustice, exclusion, oppression and so on can be expressed in religious terms, as these authors do, the problems they refer to are not religious in themselves. Indeed, by attacking the religious establishment that supports the status quo, they show how the very same religion is used to legitimize just the opposite of their own claims. A religion that can be used to support opposing and mutually exclusive claims at the same time undermines its very nature; to a certain degree, it becomes meaningless.

In returning to Hamid Dabashi's demand for a new ideology that is capable of resisting empire, our alternative reading of empire refers us back to Dussel's distinction between center and periphery. It may be useful to extend Enrique Dussel's understanding of the center as the representation of hegemonic structures, independently whether the center is part of the "traditional" center or not, to include all groups in society that have access to power, whether it is political, economic, religious, or social power. In this reading, the representatives of the "false" religion as outlines earlier are also representatives of the center and the status quo that is built on injustice and exclusion. In consequence, the periphery includes all those who are excluded, independently of their race, religion, or ethnicity. In other words, the periphery includes the homeless in San Francisco as well as a young girl in rural Pakistan that is not allowed to attend school. Yet, accidentally, the girl in rural Pakistan and the homeless may share the same religion, but is the accidental coincidence sufficient to serve as a basis for an inclusive periphery ideology?

As Albert Hourani reminds us, for al-Afghani the one theme that runs through most of his works is unity. He believed that "[b]oth the common danger, and the values which all Muslims share, should outweigh differences of doctrine and traditions of enmity. Differences of sects need not be a political barrier" (Hourani 1979: 115). Yet, al-Afghani's biggest theme was also his biggest failure: instead of a more unified and, thus, peaceful (Muslim) world, the world has become increasingly sectarian. Whether tendencies towards religions sectarianism imply that a religion-based approach may not be the most promising one remains a different question. For al-Afghani such an approach would be unthinkable. Despite the fact that 'Ali Shari'ati refers to Camus, who quotes Dostoevsky, "[i]f we remove God from the universe, every action is legitimate.' Why? Because there will be no will, understanding, and feeling left in order to distinguish good from evil" (Shari'ati 1981: 13). The understanding that morality or ethics does not exist outside religion is a frequently asserted claim. More recently, Abdullahi Ahmed an-Na'im attempted to forcefully repeat this claim (an-Na'im 2008: 276; for a critique see Koch 2013: 128). Yet, if one follows this assumption, particularly in pluralist societies, one may be instantly faced with competing and mutually exclusive moralities, which may serve as just another basis for exclusion and oppression because, despite and independently of a shared end, the number of 
perceived "wrong" religions could easily multiply. Eventually, such approach supports the status quo. Viewed from a more global perspective, the assumption that morality or ethics outside religion is an oxymoron would necessarily lead to the periphery's increasing fragmentation.

Thus, instead of invoking a language of good and evil or sin, the language of right and wrong, ethical or unethical is a more appropriate and inclusive language. Moreover, as Enrique Dussel notes, an "ethical conflict starts when the victims of the prevailing formal system cannot live, or have been violently and discursively excluded from such a system; when sociohistorical subjects, social movements $[\ldots]$, classes $[\ldots]$, marginal groups, genders $[\ldots]$, races $[\ldots]$, peripheral impoverished countries, and so on, become conscious, organize themselves, formulate diagnoses of their of their negativity and prepare alternative programs to transform the systems that are in force and that have become dominant, oppressive, the cause of death and exclusion" (Dussel 2013: 401).

Consequently, resisting empire starts at home. Presently, one can observe numerous movements that engage locally or nationally. Among these are the recent Arab Spring movements that suffered under the lack of a uniting and unfragmented ideology. Yet, for a new ideology, it is mandatory to explore the common ground in more than just a couple of (religious) cultures and to move beyond the two different cultures this paper has touched upon; it is mandatory to explore further peripheral cultures that are marginalized and excluded to find a more global common ground that, at the same time, does not demand denial of cultural identity. If one attempts to join a movement that does not share into one's own cultural identity, although it shares similar goals, as Camilo Torres reminds us, becoming the other movement's "useful idiot" has to be avoided (Torres 1971: 287-9). Similarly, Camilo Torres regards only (he writes in the context of the Cold War from a particularly Latin American perspective; under other circumstances he may have included Islam) Christianity and Marxism as complete and integrated Weltanschauungen that allow for the creation of a movement that succeeds in structural change. What this project is eventually aiming at may be phrased as a federal ideology of liberation, building on Johannes Althusius's (1981) federal and consocial legacies.

\section{Conclusion: Three Challenges}

An ideology of liberation faces numerous challenges. These challenges exist independently of the global or regional nature of the movement. First, if a local movement builds its ideology primarily on religious ethics, it faces the problem of religious radicalization. As historic as well as contemporary empirical evidence indicates (Koch forthcoming), most "religious" conflicts did not start as religious conflicts, but as conflicts over resources, inclusion and exclusion, and socioeconomic and political injustice. Yet, if the origin of a conflict remains, it is likely that the conflict is reinterpreted in religious language and eventually turns into a conflict over competing religious truths. 
Second, whether under the dogma of the Cold War or whether under the dogma of the global war on terror, most conflicts are conflicts that involve local peripheries and centers. If the local elite (center) belongs to the international terror or anti-terror network, it will likely use terrorist threats as a justification for violent actions against peripheral protest movements. If the center is part of the US national security system, Hélder Câmara's concern of the 1960s in Brazil remains relevant. Although Câmara rejects violent resistance primarily out of personal conviction, he also rejects it for pragmatic reasons: he fears that popular violent uprising may provoke a military intervention by the "great power" (Câmara 1970: 53). Thus, the existing or emerging legitimacy crisis is not solved, but temporally "appeased" through violent suppression of resistant movements, which makes the emergence of increasing counter-violence likely. Consequently, in order to solve the conflict between periphery and center, not only the underlying problems of exclusion and injustice have to be solved, but the (vicious) circle of violence and counterviolence has to be interrupted.

The third challenge concerns a successful peripheral movement: if a peripheral movement succeeds, it may turn into a new hegemony. To phrase it with Enrique Dussel, "the victims who were once homeless end up installing beautiful fences to protect their newly acquired comfort from others who are the new poor," excluded, or heterodoxy (Dussel 2013: 427).

\section{References}

Ahmed, A. 2013. The Thistle and the Drone: How America's War on Terror Became a Global War on Tribal Islam, Washington, D.C.: Brookings Institution Press.

Al-Afghānī, Jamāl ad-Dīn. 1983. Answer of Jamāl ad-Dīn to Renan, Journal des Débats, May 18, 1883. In N. R. Keddie, An Islamic Response to Imperialism: Political and Religious Writings of Sayyid Jamāl ad-Dīn "al-Afghān̄̄," Berkley: University of California Press, 181-90.

—. 1983a. Lecture on Teaching and Learning. In N. R. Keddie, An Islamic Response to Imperialism: Political and Religious Writings of Sayyid Jamāl ad-Dīn "alAfghānī," Berkley: University of California Press, 101-8.

—. 1966. Despotic Government. In L. M. Kenny, "Al-Afghānī on Types of Despotic Government," Journal of the American Oriental Society 86, 1, 19-27.

Althusius, J. 1981 [1614]. Politica Methodice Digesta atque exemplis sacris \& profanis illustrata, 2 nd reprint of the 3rd ed., Aalen: Scientia.

Bashir, H. 2013. Europe and the Eastern Other: Comparative Perspectives on Politics, Religion, and Culture before the Enlightenment, Lanham: Lexington.

Câmara, H. 1970. Violence in the Modern World. In Peruvian Bishops', Commission for Social Action (ed.), Between Honesty and Hope: Documents from and About the Church in Latin America, Maryknoll Publications: Maryknoll, N.Y., 47-54.

Chatterjee, K. 2011. 'Ali Shari'ati and the Shaping of Political Islam in Iran, New York: Palgrave Macmillan.

Comblin, J. 1998. Called for Freedom: The Changing Context of Liberation Theology, Maryknoll: Orbis. 
—. 1979. The Church and the National Security State, Mayknoll: Orbis.

Dabashi, H. 2008. Islamic Liberation Theology: Resisting the Empire, London: Routledge.

Dallmayr, F. 2008 Comparative Political Theory: What is it Good For? In T. Shogimen and C. J. Nederman (eds.), Western Political Thought in Dialogue with Asia, Lanham: Lexington, 13-24.

Dussel, E. 2013. Ethics of Liberation: In the Age of Globalization and Exclusion, Durham: Duke University Press.

Ellacuría, I. 1976. Freedom Made Flesh: The Mission of Christ and His Church, Maryknoll: Orbis.

French, J. H. 2007. A Tale of Two Priests and Two Struggles: Liberation Theology from Dictatorship to Democracy in the Brazilian Northeast, The Americas 63: 409-443.

Gismondi, M. A. 1986. Transformations in the Holy: Religious Resistance and Hegemonic Struggles in the Nicaraguan Revolution, Latin American Perspectives $13,3,13-36$.

Gutiérrez, G. 1988. A Theology of Liberation: History, Politics and Salvation, 15th anniversary ed., Maryknoll: Orbis.

Hourani, A. 1970. Arabic Thought in the Liberal Age, 1798-1939, Oxford: Oxford University Press.

Jansen, J. J. G. 1997. The Dual Nature of Islamic Fundamentalism, Ithaca: Cornell University Press.

Kippenberg, H. G. 2011. Violence as Worship: Religious Wars in the Age of Globalization, Stanford: Stanford University Press.

Koch, B.. 2013. "Religious Freedom and Majority Rule: Marsilius of Padua 'on' Abdullahi Ahmed an-Na'im and the 'Secular' Islamic State," Politics and Religion 6, 1, 121-144.

—. Forthcoming. Legitimizing Political Violence: Islamic and Christian Traditions and Legacies in Transcultural Perspective, Berlin/Boston: De Gruyter.

Na'im, A. A. an-. 2008. Islam and the Secular State: Negotiating the Future of Shari 'a, Cambridge MA: Harvard University Press.

Osborn, R. T. 1983. Some Problems of Liberation Theology: A Polanyian Perspective, Journal of the American Academy of Religion 51, 1, 79-95.

Pottenger, J. R. 1989. The Political Theory of Liberation Theology: Towards a Reconvergence of Social Values and Social Science, Albany: State University of New York Press.

Shari'ati, A. 1986. What is to be Done: The Enlightened Thinkers and an Islamic Renaissance, ed. Farhang Rajaee, foreword John L. Esposito. North Haledom: Islamic Publications International.

- 1981. Man and Islam, ed. and trans. Fatollah Marjani. Houston: Filinc.

Torres, Camilo. 1971. "Revolution: Christian Imperative." In John Gerassi (ed.), Revolutionary Priest: The Complete Writings \& Messages of Camilo Torres, New York: Random House, 261-290.

—. 1971a. "Two Subcultures." In John Gerassi (ed.), Revolutionary Priest: The Complete Writings \& Messages of Camilo Torres, New York: Random House, 256-260.

Tripp, C. 2013. The Power and the People: Paths of Resistance in the Middle East, Cambridge: Cambridge University Press. 